\title{
PRÁCTICAS Y DISCURSOS PEDAGÓGICOS EN TOCONAO. CUlTurA, PATRIMONIO E INTERCULTURALIDAD
}

\author{
Ramiro Catalán ${ }^{1}$
}

\begin{abstract}
Resumen
Se analizan los procesos de implementación del Programa de Educación Intercultural Bilingüe (PEIB) orientado al pueblo licanantay, específicamente en la escuela de Toconao (comuna de San Pedro de Atacama). Se pone énfasis en las prácticas y discursos pedagógicos que construyen ciertas representaciones étnicas desde la escuela, y que se establecen como un espacio de re-elaboración de nociones sobre lo étnico, lo intercultural y "lo licanantay". Presentamos varios ejes de análisis en los cuales se puede articular una comprensión antropológica sobre la tensión entre la función homogeneizadora de la escuela y el nuevo papel de estímulo a las diferencias culturales, y a la diversidad que le asignan las políticas públicas educativas en el contexto de la Ley Indígena 19.253 y la Reforma Educativa. Finalmente, aportamos discursos y prácticas registradas etnográficamente para plantear la complejidad de los procesos de negociación y resistencia que ocurren en la escuela, bajo la óptica de llevar a cabo la "educación intercultural".
\end{abstract}

Palabras claves: educación - interculturalidad - etnicidad - Atacama - norte de Chile - Andes Centro-Sur.

\begin{abstract}
This paper analyzes the process of implementation of the Programa de Educación Intercultural Bilingüe (PEIB; Intercultural Bilingual Education Program) focused the Licanantay people, specifically at the Toconao School (San Pedro de Atacama). We examine the schooling practices and discourses that construct representations about the ethnic, intercultural, and Licanantay identities. This article presents seven axes of analysis that articulate an anthropological view about the tension between the homogenizing practices of the school and a new position that Indigenous Law 19.253 and Education Reform allegedly have regarding cultural diversity and cultural differences. In this sense, I will also provide schooling discourses and practices to discuss the complexity of the negotiation and resistance processes that emerge in the Toconao School surrounding intercultural education.
\end{abstract}

Key words: education - interculturality - ethnicity - Atacama - Northern Chile - South Central Andes.

Recibido: enero 2013. Aceptado: marzo 2013.

\section{* Introducción: Antecedentes sobre la IMPLEMENTACIÓN DE LA EDUCACIÓN INTERCULTURAL EN CHILE}

Desde los años 9o, en Chile se viene desarrollando una Reforma Educativa que, entre una serie de aspectos, incorpora el Programa de Educación Intercultural Bilingüe (PEIB) en escuelas, coordinado por el Ministerio de Educación. Este programa surgido en 1996 está basado en la promulgación de la Ley 19.253 de 1993, conocida como Ley Indígena, y se orienta principalmente a escuelas rurales en regiones de Chile con población indígena, según la identificación dada por el Estado en el marco de dicha ley, que establece diversas acciones y programas de supuesto carácter compensatorio para las personas que se autoidentifiquen como indígenas y demuestren ser descendientes de grupos originarios, a partir de la categoría establecida desde el Estado. En ese sentido, la EIB se plantea como una forma de generar en las escuelas con alumnado de ascendencia indígena programas educacionales contextualizados culturalmente que promuevan el reconocimiento y valoración de su pertenencia étnica.

Esta nueva institucionalidad orientada en un primer momento a desarrollar iniciativas piloto, comienza a generar un marco de orientación enfocado a ampliar el espectro de escuelas integradas al programa. En este punto también es relevante el aporte y coordinación con la Corporación Nacional de Desarrollo Indígena (CONADI), para enfatizar los objetivos tendientes a establecer una educación sustentada en la pertinencia cultural de los contenidos y prácticas pedagógicas.

\footnotetext{
1 Programa de Bachillerato en Ciencias Sociales y Humanidades, Facultad de Ciencias Sociales e Historia, Universidad Diego Portales. Av. Ejército 333, Santiago, CHILE. Email: ramcatalan@yahoo.com
} 
En este proceso de ir cimentando la importancia de establecer una EIB focalizada en escuelas rurales en contextos de población indígena, surge en el año 2001 un importante impulso a través del Programa Orígenes, financiado con fondos del BID y del Gobierno de Chile.

Desde su instauración, el Programa Orígenes y su componente de Educación comienzan a trabajar con el PEIB del Ministerio de Educación focalizándose en 162 escuelas rurales con población indígena ${ }^{2}$. En este sentido, las tareas que se establecen para la primera fase (20022005) de desarrollo del Programa son:

"Adecuación del currículum escolar a las particularidades culturales y lingüisticas de cada pueblo focalizado, publicándose textos escolares pertinentes de $1^{\circ}$ a $4^{\circ}$ de enseñanza búsica.

- Capacitación y perfeccionamiento de docentes en Educación Intercultural Bilingüe (EIB).

- Creación de bibliotecas y edición de textos con contenido intercultural.

- Habilitación e implementación de tecnologías de la información y de las comunicaciones: computadores, equipo audiovisual, núcleos de internet, edición de videos y software, televisión satelital y adquisición de programas televisivos con contenido cultural.

Elaboración de planes educacionales con EIB en las escuelas" (Mideplan 2006: 40-41).

Los proyectos de EIB llevados a cabo en las escuelas, tenían por objeto valorizar el contexto cultural de los alumnos a través del desarrollo de textos escolares con pertinencia cultural y la inserción de asesores culturales o educadores tradicionales. Se debía tratar de personas de la comunidad que apoyaran al docente como monitores pedagógicos reforzando determinados contenidos en donde fuera necesario un conocimiento local y étnico. Además de los textos y educadores tradicionales, otro pilar de estas iniciativas era la contextualización de conte-

\footnotetext{
2 De las 162 escuelas focalizadas por el Programa en esta primera fase, se mantuvieron 112 de ellas. Sin embargo, a esta disminución le sigue luego la incorporación de nuevas escuelas llegando a un total de 274 en el año 2008.
}

nidos curriculares con atención a la pertenencia cultural de los alumnos.

\section{* Aproximaciones desde la antropología DE LA EDUCACIÓN}

El foco de la investigación, orientado a dar cuenta de los procesos desencadenados por la educación intercultural y las representaciones que surgen desde la institución escolar sobre la comunidad, fueron abordados desde el análisis de los discursos y prácticas presentes en la escuela. ${ }^{3}$

"En la etnografía como proceso de comunicación cabría destacar dos aspectos, también relevantes para el estudio de la educación $y$ de las instituciones escolares. El primero redefine la acción social como acción significativa (Geertz) y la actividad etnográfica como captación de significados tanto implícitos como explícitos" (Velasco et al. 2006: 17).

Cuando Geertz (1997 [1973]) señala la importancia de la interpretación de los datos como un proceso descriptivo complejo también expresa la capacidad de la etnografía para abordar discursos y prácticas sociales complejas, susceptibles de ser descritas y comprendidas mediante un análisis detallado de lo observado.

La antropología, durante su desarrollo como disciplina científica, siempre ha manifestado una especial preocupación por la educación como un campo de interés para pesquisar las modalidades en que se reproducen los modos de vida de las sociedades. Ya sea desde los procesos de socialización investigados por la antropología clásica en culturas pretendidamente insulares hasta el papel actual que juega la educación formal construida desde el Estado moderno, la educación, entendida como un mecanismo de producción y reproducción cultural, se erige como vital para entender el funcionamiento de las sociedades.

Los primeros análisis sobre el tema de la educación y el rol de la institución escolar parten desde las distintas

\footnotetext{
3 Como parte de la investigación se emplearon diversas técnicas de recolección de información con el fin de obtener una comprensión cabal del tema. Observación etnográfica en aula y en espacios de la escuela, entrevistas semi-estructuradas y en profundidad a profesores y directivos, además de conversaciones con alumnos. También se participó de reuniones y festividades de la comunidad.
} 
posturas teóricas que emergen, por una parte, con la concepción de la educación como transmisión de cultura (Mead 1967 [1928]), y por otra, con el planteamiento de que la educación puede ser un motor de cambio (Bourdieu y Passeron 1977; Willis 2006 [1981]).

"Con frecuencia, los etnógrafos han forjado su visión de las escuelas alrededor del concepto de transmisión cultural. Bajo este punto de vista, la escuela actúa primordialmente como un agente de la cultura, transmitiendo un conjunto complejo de actitudes, valores, comportamientos y expectativas que permitirán a una nueva generación mantener la cultura como un fenómeno en continuidad (Spindler 1955, 1963a; Kimball 1974). Este tipo de análisis se encuentra en la tradición estructural-funcional del pensamiento científico-social. Los etnógrafos a menudo han utilizado sus conocimientos contextuales de la cultura en su totalidad para ilustrar sus investigaciones de lo que se transmite en la escuela" (Wilcox 2006 [1982]: 102).

En la otra línea se presenta la corriente de estudios sobre la reproducción y la teoría del campo del poder (Bourdieu y Passeron 1977; Bourdieu 2006 [1989]), y las distinciones entre producción y reproducción (Willis 2006 [1981]), que presentan aproximaciones complejas a la institución escolar pendiente de una tensión entre la estabilidad y el cambio.

Ante ese enfoque de continuidad y discontinuidad, los cambios estimulados en la institución escolar, sean a nivel de políticas públicas o de cambios en el modo de practicar la educación por sus actores, mantiene la incógnita por el cotidiano desenvolvimiento de sus procesos y hasta qué punto plantean alteraciones de fondo al modo de producir (o reproducir) cultura.

"El trabajo etnográfico tiende a sugerir que es muy dificil introducir cambios significativos en el marco del aula. Una reforma puede ser instituida por decreto, pero se pueden observar fuertes continuidades con las disposiciones anteriores, aunque las formas en las que la continuidad se exprese puedan variar en algo. Se necesita un enfoque sensible y abierto para percibir la nueva forma en que resurgen las viejas dinámicas" (Wilcox 2006 [1982]: 109).

La cita anterior es muy pertinente si se piensa que este trabajo remite a la introducción, más o menos reciente, de una nueva temática a la institución escolar con pre-

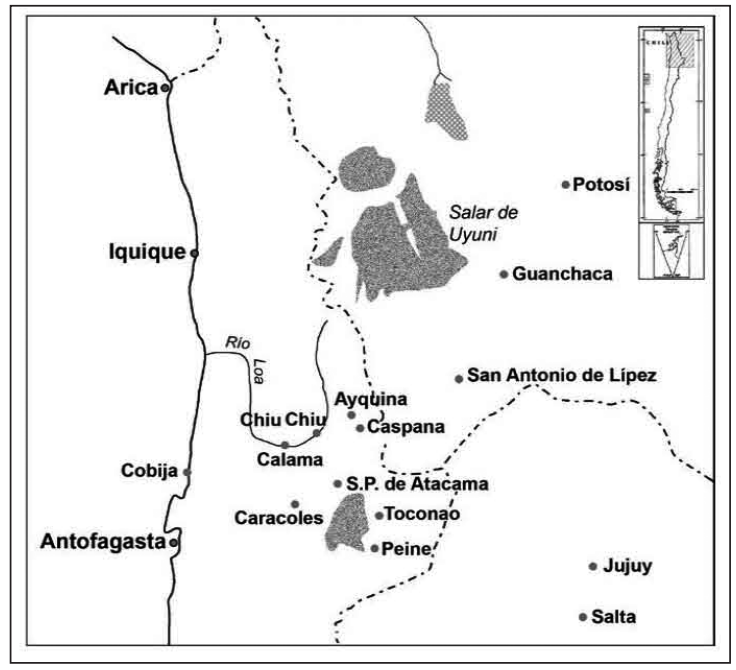

Figura 1. Ubicación de la localidad de Toconao en la comuna de San Pedro de Atacama. Tomado de Sanhueza y Gundermann (2007).

sencia de alumnado de origen étnico: la educación intercultural. Más aún, considerando que esto ocurre en un contexto de reforma educacional en Chile. Por lo tanto, resulta interesante pesquisar cuál es la cotidianidad en este proceso de transformación (si es que hay transformación), y cómo se despliegan las relaciones entre el modelo anterior (percibido, recordado y valorado por los docentes) y los esfuerzos (si los hay) por institucionalizar el cambio (en expectativas, resistencias y prácticas de docentes).

\section{* La localidad de toconao ${ }^{4}$ y la comuna de San Pedro de Atacama}

En el s. XX se produjeron importantes transformaciones en el modo de vida de las poblaciones asentadas en las localidades cercanas a San Pedro de Atacama (Figura 1). El auge de la minería, por ejemplo, sobre todo la del cobre, motivó una fuerte transformación en la economía

4 La localidad de Toconao se ubica en la región de Antofagasta, a una altura de 2.475 m.snm forma parte de la comuna de San Pedro de Atacama, situada en pleno desierto de Atacama, a 1.670 $\mathrm{km}$ al norte de la capital del país. La población total de la comuna es de 4.969 habitantes según el Censo Nacional 2002. De ellos, 732 son de Toconao. 
local a través del ingreso como mano de obra de bastante población a un sistema asalariado capitalista. Lo anterior, acompañado de la creciente actividad turística, ha ido mermando progresivamente la tradicional centralidad de las labores agrícolas en las localidades.

A pesar de que en algunas zonas de la región se percibe todavía cierta presencia de estructuras tradicionales agrícolas, sobre todo en los ayllu más distantes de la localidad de San Pedro de Atacama, esta presencia es muy marginal. Sin embargo, el control sobre los territorios de estos ayllu sigue siendo relevante pues puede determinar un grado de poder en la asociación indígena en cuanto comunidad jurídica e interlocutor ante el Estado chileno.

En este sentido, el papel del Estado, y posteriormente del municipio, regulado por la Ley Indígena, ha trazado importantes transformaciones sociales, políticas y económicas en la comunidad de San Pedro de Atacama, que han estimulado la emergencia de nuevos actores sociales al interior de la comunidad, siendo las asociaciones indígenas uno de los más significativos (Gundermann 2003).

"Frente a la minería, San Pedro es, a la vez, proveedora de fuerza de trabajo (atraída por los ingresos y la seguridad social relacionada), espacio de repliegue (ante crisis de precios en el mercado internacional de los metales) y espacio de retiro (la fuerza de trabajo gastada, jubilada, desahuciada). Ello tiene una consecuencia estructural sobre las actividades agropecuarias: salvo algunos casos particulares, estas son secundarias y muchas veces insignificantes en las economías atacameñas" (Gundermann 2004: 227).

A esto se suma en la actualidad el turismo, como importante factor a considerar en las transformaciones de las comunidades ubicadas en esta región. Pues desde mediados de los años 9o, San Pedro de Atacama pasó a convertirse en un destino turístico de primera relevancia en Chile, y fuerte polo de atracción de turismo extranjero por su paisaje desértico, y su arquitectura patrimonial bien conservada, entre otros (Gundermann 2004).

\section{* Lo intercultural y lo multicultural}

Aunque estrechamente relacionados, "intercultural y multicultural no son sinónimos" (Rockwell y Gó- mez 2009: 108). La multiculturalidad producida en Norteamérica y Europa propone cómo generar políticas de reconocimiento de derechos a la diversidad de comunidades presentes en el contexto del Estado nación (Taylor 1994). En ese sentido, la existencia de una "ciudadanía multicultural" (Kimlicka 1995) plantea la discusión sobre cómo desde el Estado que fija derechos individuales también puede generarse un estatus de "derechos colectivos" sobre minorías. Por otra parte, lo intercultural se tiende a asociar con la interacción y el contacto entre culturas. De este modo, la educación intercultural trata, en un sentido general, sobre cómo el Estado nación a través de sus políticas educativas lleva a cabo "políticas de la diferencia" que buscan generar un trato compensatorio hacia las minorías, orientadas fundamentalmente - para el caso latinoamericano- a los grupos étnicos.

"En América Latina, por último, tanto la crítica al legado homogenizador del indigenismo como la influencia de agencias europeas de cooperación internacional contribuyen al paulatino paso - hasta la fecha a menudo solo terminológico - de la 'educación indígena bilingüe bicultural' a la educación intercultural" (Dietz 2003: 61-62).

Tributaria de esas orientaciones, las políticas de educación intercultural en Chile se basan en un enfoque compensatorio focalizado en los pueblos indígenas (Cañulef 1996, 1998; Chiodi y Bahamondes 2001; Hernández 2004; Hevia 2005; Williamson 2004, 2012). Esta política educacional fomenta el desarrollo de "una educación para la diversidad" pero dirigida especialmente hacia el mundo indígena, y sobre todo aquel que vive en el mundo rural (Hernández 2004). Es ahí donde su corte multiculturalista queda reducido, en definitiva, a una educación "para la comunidad indígena" (Álvarez $2003 \mathrm{Ms}$ ). En ese sentido, el desplazamiento, en teoría, desde un modelo "monocultural" del sistema educativo a uno de "interculturalidad" no cubre la diversidad de realidades escolares (urbanas, rurales, municipales, privadas, subvencionadas, con alumnado de adscripción étnica, con alumnado sin adscripción étnica, entre otras variables), y queda supeditada a la tríada ruralmunicipal-área indígena.

En el caso específico de la aplicación de la educación intercultural en el contexto atacameño, es relevante 
considerar que históricamente existieron agrupaciones de docentes en la región, que décadas antes ya solicitaban una educación focalizada a las particularidades de la escuela rural atacameña que incluyera contenidos con pertinencia cultural (Gómez 1995). Esa necesidad se fortalecerá con las negociaciones que a comienzos de los 90, potenciadas por la conmemoración del Quinto Centenario, llevarán a cabo los distintos pueblos indígenas para discutir con el Estado post-dictadura una Ley Indígena que, entre otros derechos, impulse políticas educacionales específicas para ellos (Cañulef 1998).

En cuanto al carácter que adoptan las políticas de educación intercultural, algunos autores constatan que la pedagogía intercultural emplea habitualmente el concepto de cultura en un sentido decimonónico, esencialista y rígido que confunde nociones de cultura, etnia o grupo (Dietz 2003). Investigaciones recientes sobre la institución escolar en espacios multiculturales, por ejemplo en escuelas de España con presencia de alumnado migrante, señalan cómo la escuela pretendidamente intercultural procesa las diferencias culturales según una determinada noción de cultura generando diferenciaciones, marcas étnicas, y valorando de forma desigual los capitales sociales del alumnado (Díaz de Rada 1996; Franzé 2003; Jociles 2003).

Algunas de estas perspectivas señalan la importancia de indagar en los usos y abusos del concepto de cultura en la educación intercultural (Carrasco 1997), contrastando con la noción antropológica de cultura, entendida como contexto de construcción de sentido negociado y validado intragrupalmente (Geertz 1997 [1973]). Lo que también conecta con los procesos de diferenciación intercultural e identificación intragrupal que confluyen al fijar supuestas diferencias culturales para establecer fronteras étnicas (Barth 1982).

En el caso específico de la educación intercultural en el contexto indígena en América Latina, se hace evidente la importancia que adquieren las nociones de bilingüismo, etnicidad y la construcción del concepto de pueblos indígenas desde los diferentes programas educativos del Estado (Chiodi y Bahamondes 2001; Dietz 2003; Rockwell y Gómez 2009; Szulc 2009).

\section{* Prácticas pedagógicas y discursos ASOCIADOS A LO INTERCULTURAL EN LA ESCUELA DE TOCONAO}

Los discursos pedagógicos que se construyen en la escuela de Toconao denotan también esa polisemia recurrente del concepto de interculturalidad5. Van entregando representaciones que se construyen desde las distintas miradas y experiencias de los docentes, pero que manifiestan como núcleo común el estar amparadas en esa función de "procesar cultura" que caracteriza a la institución escolar en tanto brazo activo del Estado nación. Así, esa suerte de ferrocarril que partió en el s. XIX llegando a los lugares más distantes del país cargado de la ideología de una homogeneización nacional y la anulación de las diferencias étnicas, lingüísticas y locales, trata ahora, según las políticas educativas prointerculturalidad, de deshacer su recorrido. Aunque no es la idea extremar la analogía mencionando un peligro de "descarrilamiento" en algunas áreas de ese proyecto, sí es relevante mencionar lo paradójico que resulta utilizar el mismo medio homogeneizador de conocimientos (la escuela) para ahora legitimar (supuestamente) y fomentar las diferencias, valorar la diversidad y construir espacios interculturales.

Ahora bien, ese relato de interculturalidad que circula en las escuelas rurales en la comuna de San Pedro de Atacama es un relato fragmentario, incompleto y que mezcla diversas nociones y representaciones de los agentes involucrados. $^{6}$

Lo que está latente en ese discurso fragmentario, y a la vez acotado a espacios y tiempos muy específicos dentro de la cotidianidad escolar, es el trazo irregular con el

5 La escuela de Toconao forma parte de la comuna de San Pedro de Atacama. Cuenta con cerca de 140 alumnos que se distribuyen en cursos de $1^{\circ}$ a $8^{\circ}$ Básico ( 6 a 13 años de edad), con un promedio de 15 a 20 alumnos por curso. Al ser la única escuela básica de la localidad gran parte de sus alumnos provienen de ella. La otra escuela cercana está en la localidad de San Pedro de Atacama, a unos $30 \mathrm{~km}$ de distancia. Además del director y del jefe de UTP, encargado de coordinar el trabajo pedagógico de los profesores, la dotación docente durante el año 2009 era de ocho profesores, de los cuáles siete eran mujeres.

6 Estudios recientes sobre estos procesos se han llevado a cabo en la comuna de San Pedro de Atacama (p.e., Gómez 1995; Hernández y Thomas 2004; Bolados 2006). 
que se van construyendo las distintas representaciones de lo intercultural y donde emergen nociones en torno a lo auténtico, lo originario, lo tradicional, el esencialismo indígena, lo patrimonial, entre muchas otras referencias. Que oscila desde la agencia más comprometida de parte de los docentes entrevistados que se autorreconocen como atacameñas/os, hasta el desdén o la abierta oposición al proyecto intercultural de parte de otros docentes y directivos.

\section{Lo intercultural como el pretendido paso de la homogeneización a la diversidad cultural}

La labor de homogeneización llevada a cabo por los sistemas educativos organizados por el Estado nación desde el s. XIX, se fundaban en la premisa de bloquear las diferencias culturales de etnias y grupos autónomos al interior de los Estados fomentando una educación que transmitiera valores, símbolos y normas intencionadamente nacionales y homogéneas. Ocultar las diferencias y la diversidad, y construir una imagen nacional que congregara y unificara a la población detrás de una idea de comunidad, era parte también de ese proceso (Anderson 1993).

Así, la llegada de la educación primaria a las comunidades indígenas de América Latina marca un proceso parecido al de la evangelización en los siglos XVI y XVII. Pues si bien en ese caso, la intención era la llamada extirpación de idolatrías, en esta incursión de la institución educativa en las comunidades se buscaba principalmente imponer el idioma oficial de la nación (castellano) sobre la lengua étnica (kunza, en el caso de los licanantay). También ensalzar mitos e historias de los héroes independentistas criollos por sobre las historias y los héroes locales indígenas, y cambiar los repertorios simbólicos y prácticas culturales étnicas por un nuevo concepto de sujeto, el ciudadano nacional.

Estos procesos tienen un correlato en el establecimiento de una educación nacionalista, opuesta a las particularidades culturales de las comunidades, pero no solo a nivel de contenidos y repertorios sino también como cambio de paradigma educativo, de uno oral -en muchos casosa uno escrito. Al mismo tiempo, también se reestructuran y reformulan una serie de dispositivos y modalidades de transmisión de conocimiento que se reconfiguran de manera distinta a las que tradicionalmente podían darse en estas comunidades indígenas.

Para el caso de las etnias del norte de Chile, sobre todo aymara y licanantay, este proceso de homogeneización cultural llevado por la educación también tuvo una doble etapa, pues a la distinción dada entre lo indígena y lo nacional se superpuso la noción de un nacionalismo chileno frente a uno boliviano 7 . Hasta antes de la Guerra del Pacífico (1879-1884) esos territorios formaban parte del Estado boliviano y las poblaciones ahí establecidas, y que se movían por ese espacio como un etnoterritorio reconocido por ellos como "abierto", pasaron de un momento a otro de ser bolivianos a ser chilenos, al menos en la nomenclatura dada por la lógica del Estado nación.

"Es fácil advertir que todos estos cambios en términos administrativos, solo consiguieron demarcar fronteras en un territorio percibido por los atacameños como uno solo. Para los pastores y arrieros de la Puna de Atacama, su espacio natural de desplazamiento y dominio es una amplia región que supera los limites político-fronterizos. Las actividades mineras, pastoriles, comerciales, trueque, contrabando y contactos familiares, antes $y$ ahora, dan cuenta del tradicional manejo de los atacameños sobre un gran territorio que se sostenía a través del traslado de recursos deseados agüende y allende los Andes" (Núñez 2007: 256).

Esto supuso para la educación chilena de comienzos del s. XX un doble esfuerzo, reducir la heterogeneidad de lo indígena en esta zona a una homogeneidad nacional, y al mismo tiempo, reforzar y acentuar lo nacional chileno como contraparte de lo nacional boliviano, ante la cercanía del recuerdo histórico, y también de la frontera geográfica.

En este sentido, opera una estrategia de "nacionalismo nacionalizante" (Brubaker, cit. en Dietz 2003) sobre la otredad para incorporarla al proyecto de nación pero despojada de cualquier atisbo de diferencia, heterogeneidad, diversidad. Sin embargo, el proceso de homogenización, que deviene en legitimar la otredad como

\footnotetext{
7 En este mismo sentido, cabe consignar la situación geográfica de esta zona, ubicada cerca de la triple frontera con Bolivia y Argentina.
} 
"nuevo integrante de la nación", se realiza mediante la cancelación de su diferencia lingüística, la suspensión de su autonomía local, y la inserción en un sistema económico capitalista donde ingresará en desigual posición.

Ahora bien, la maquinaria homogeneizadora de la educación chilena comienza a cambiar desde finales del s. XX, con la irrupción de las propuestas y programas de EIB. Por supuesto, este proceso no es gratuito ni unilateral, pues requiere de las presiones de los pueblos indígenas atravesadas por demandas de reconocimiento, legitimidad social y política desde sus diferencias como comunidad, y también las presiones de circunscribir tratados internacionales como el Convenio OIT 169.

Esta nueva mirada, que en el discurso del PEIB busca valorizar lo indígena, revitalizando el uso del lenguaje de los pueblos originarios, recuperar contenidos y elementos característicos de cada etnia, planteará un nuevo escenario signado por una política intercultural que pondrá su acento en la diferencia, más específicamente en la construcción de diferencias culturales bajo la premisa de poder distinguir, separar y aislar aquellas características "primordiales" de cada pueblo indígena. Esta definición surge desde el Ministerio de Educación, quien definirá, aun a través de consultas, "participación" y negociación con representantes y agrupaciones del mundo indígena, lo que será propio de cada etnia.

Siguiendo la definición de interculturalidad funcional de Tubino, ésta sería un ajuste dentro del discurso oficial del Estado nación, pero en ningún caso representaría un riesgo de cambio a su sistema, como sí sería la adopción de una perspectiva de interculturalidad crítica (Tubino cit. en Ferrao 2010). Lo cual parece sugerente, toda vez que la política educativa intercultural producida desde el Estado chileno mantiene el control de la legitimidad sobre lo "culturalmente permitido" en una perspectiva más bien bicultural para el caso atacameño (Bolados 2006). Y como veremos más adelante, aunque la escuela construya un relato sobre la diversidad cultural, sus mecanismos de procesar la cultura inevitablemente generan representaciones sobre lo étnico que tienden a ser homogéneas, esencializadas y narradas en tiempo pasado. Aparece entonces la imagen de una interculturalidad funcional:
"Se trata de 'promover el diálogo y la tolerancia sin afectar las causas de la asimetría social y cultural actualmente vigentes' (Tubino 2005: 5). Las relaciones de poder entre los diferentes grupos socioculturales no son puestos en duda. De esta manera, el interculturalismo funcional tiende a disminuir las áreas de tensión $y$ conflicto entre los diversos grupos y movimientos sociales, cuyo foco de atención son las cuestiones socioidentitarias, evitando que la estructura y las relaciones de poder vigentes sean afectadas" (Ferrao 2010: 338).

En esta estrategia de revalorización de lo étnico, también toma parte un nuevo actor de la escuela, el "educador tradicional”, elegido por la asociación indígena respectiva por su etno-conocimiento, para que, en compañía del profesor, pueda apoyar la clase denominada "Patrimonio Cultural" que presentará las tradiciones de la cultura licanantay. Además, el educador tradicional eventualmente apoyará la elaboración de textos escolares contextualizados culturalmente apoyado en su conocimiento local. Es el espacio concedido a la comunidad dentro de los intersticios de la escuela.

En ese sentido, a pesar que el Ministerio de Educación mantiene el control sobre los contenidos mínimos obligatorios que deben ser transmitidos por la escuela, surge un espacio de aplicación particular donde ésta, localmente, deberá desarrollar esos contenidos dotándolos de etnicidad y pertinencia cultural.

El educador tradicional también tendrá la potencial tarea de ser un nexo entre la comunidad y la escuela. Por ejemplo, para facilitar la participación de la comunidad en el Proyecto Educativo Institucional (PEI) de la escuela, el cual marca los objetivos y estrategias pedagógicas de ella, y que trata de complementar, por una parte, la obligatoriedad del currículo definido por el Ministerio de Educación en los Objetivos Fundamentales y Contenidos Mínimos Obligatorios (OF-CMO) que recibirán los alumnos, y por otra, elaborar planes y programas propios con acuerdo a las particularidades específicas de cada escuela.

Es en este contexto complejo y con múltiples factores en juego donde se sitúa el trabajo con EIB en la escuela de Toconao. Es desde ese lugar donde se desarrollan las prácticas y se construye el discurso de los actores que nos permite identificar algunos factores relevantes que 
complejizan el pretendido trabajo de interculturalidad en la escuela.

\section{Lo intercultural conceptualizado como rescate de la cultura}

"Luego de visitar las salas de clases de todos los cursos, llama la atención la escasa referencia en paredes y murales sobre cualquier referencia a lo atacameño. Salvo dos salas, la del curso de la profesora casada 'con atacameño' -según ella se presentó-, y la de otra que también ha señalado que 'la cultura atacameña aún se mantiene. Aun así las referencias son leves, en una sala un mapa de Chile pegado a la pared muestra en las distintas regiones cuadros con algo que caracteriza al lugar, así como sobre Isla de Pascua se dibujan unos moáis, sobre la región en que se ubica Toconao hay unos dibujos fotocopiados de algún libro que muestra el Pucara de Quitor ${ }^{8}$, y también el dibujo de unos arqueólogos desenterrando algo de la tierra. En el caso de la otra sala, en las paredes hay pegados algunos dibujos de llamas como referencia a la ecología del lugar" (Diario de campo escuela de Toconao 2008).

Esta imagen de la escuela que no escenifica ni reconoce su carácter de escuela núcleo del PEIB (como es considerada en los informes del Ministerio) contrasta con la relevancia focalizada que se le da a los contenidos étnicos en la clase de "Patrimonio Cultural", donde sí aparece un tratamiento distinto.

La EIB no está incorporada transversalmente en la rutina escolar, como recomiendan los planes y programas del Ministerio de Educación, sino que aparece en la sala de clases discontinuamente en asignaturas como matemáticas, comprensión del medio, o lenguaje y comunicación. $\mathrm{Y}$ el hecho que se focalice en un sub-sector denominado "Patrimonio Cultural" refuerza aún más el carácter encapsulado de los contenidos pedagógicos que se asociarán a lo licanantay. Esto también es señalado por Bolados (2006), de acuerdo a sus análisis de los discursos de los docentes en la comuna de San Pedro de Atacama.

Este encapsulamiento de los contenidos de EIB en la clase de "Patrimonio Cultural" influye en que las otras asignaturas queden libres de exigirse contextualizar sus contenidos o trastocar su modo de enseñar.

\footnotetext{
8 Fortaleza prehispánica ubicada cerca de San Pedro de Atacama.
}

El mismo formato de taller que adquiere la clase de "Patrimonio Cultural", al desarrollarse en todos los cursos durante dos horas pedagógicas a la semana, tampoco ayuda a poner en escena lo intercultural en una variedad de espacios escolares. Más bien se caracteriza por mostrar a la profesora jefe del respectivo curso acompañada por la educadora tradicional impartiendo una clase donde a los alumnos se les enseña algún cuento tradicional, se comenta alguna festividad indígena, se habla sobre vestimentas de "los antiguos", o la música que acompaña esas festividades.

"Cuando hay que tratar la parte de comprensión lectora, los profesores también se apoyan con relatos, cuentos, vivencias, tradiciones, recetas, en fin, un montón de cositas propias de la zona, y en base a eso se hace un desarrollo [...]" (Jefe UTP 2008).

"La educadora tradicional les dice a los niños: 'les voy a dar una tarea para la próxima semana, escriban, pero escúchenme bien, quiero que me traigan un cuento o una leyenda pero que sus abuelos les cuenten. Pero escúchenme bien, que les cuenten sus abuelos, mamá, papá, tíos, conocidos... pero que no sea sacada de libro. La otra vez muchos sacaron de este libro de tercero, o del libro de cuentos atacameños que está aquí en la escuela. La profesora interviene en este punto, 'ustedes tienen abuelos y los abuelos cuentan historias muy bonitas"' (Diario de campo, clase de "Patrimonio Cultural", $2^{\circ}$ Básico, junio 2008).

La interculturalidad expresada en el aula denota representaciones de lo étnico que se juegan a partir de una definición de "cultura decimonónica" (Dietz 2003). No solo se expresa como agregado de contenidos identificables que serían parte de la "cultura atacameña", sino que también se asocia a lo tradicional, los relatos, el pasado; lo que se plasma en la dicotomía entre contenidos de los textos con cuentos atacameños y los potenciales relatos de los abuelos. De alguna forma ese contraste entre texto y oralidad puede ser considerado una concesión a la expresión de la comunidad indígena y a su

\footnotetext{
9 Se refiere al Coricota Cotchaya Paunacota Lican Antay ("Cuentos de los niños atacameños"), un libro realizado por profesores de otras escuelas (uni y bidocentes) de la comuna de San Pedro de Atacama, donde se recopilan una serie de leyendas transmitidas oralmente por los ancianos de la comunidad, y a las que los profesores agregan un pequeño glosario de palabras kunza y también recomiendan algunas actividades de comprensión de lectura para trabajar el cuento.
} 
potencialidad de reactualizar conocimientos y narraciones intergeneracionales, aunque sea mediado por una actividad pedagógica.

Otro aspecto a considerar es el habitus institucional ya reproducido por los alumnos, que buscan el conocimiento sobre su cultura no en la cotidianeidad de sus relaciones sociales, sino más bien en la legitimidad dada a la palabra impresa.

Ahora bien, la educadora tradicional plantea una clase que cuenta con el visto bueno de la profesora, mediada por su "conocimiento experto" (Franzé 2003) sobre cuestiones pedagógicas, y donde la profesora participa para hacer comentarios, intervenir en la disciplina de los alumnos o apoyar pedagógicamente a la educadora tradicional. De esta manera, la demanda histórica del pueblo atacameño de incorporar al aula a personas de la comunidad señalada por Gómez (1995), queda tutelada bajo la mirada y la aprobación del docente.

Por ejemplo, en una serie de clases la educadora tradicional les enseñó a los alumnos un baile tradicional atacameño que sería presentado para la festividad religiosa de San Juan. Así los niños que quisieran participar del baile catimbano podían hacerlo e integrarse a los danzantes. Aprovechando estas clases la educadora reforzaba aspectos como la vestimenta, algunas palabras kunza utilizadas en los cantos y baile, y la fauna asociada a obtener las materias primas para las vestimentas.

En ese sentido, la definición de cultura manejada por la institución escolar relaciona patrimonio con recuperación de tradiciones, símbolos y contenidos que ya no son reproducidos socialmente o que están en proceso de no ser usados. Esa labor de "salvataje" es considerada por los mismos docentes como un "barniz", algo superficial, no sólido, como para que los alumnos que llevan "algo de atacameño" tengan algún conocimiento de lo que es, o fue (según el grado de vitalidad que le asignan a la cultura atacameña), para "saber" pero no para "ser".

"La gente cuando bajaba del interior a las reuniones de padres y apoderados, traía carnes de llamo y productos agrícolas, habas, papa negra, zanahorias, traía cebollin de Talabre, ahora no. ["Ahora también traen pero te lo venden, antes te lo regalaban" comenta otra profesora] No, si igual te lo vendían. Pero era mayor cantidad, tú lo veías. El apoderado venía también con sus tejidos. Las casas de nosotros llenas de bajadas de cama [tejidos], ahora ya no" (Profesora 5, 2008).

"Diez años atrás yo estuve trabajando cuatro años, me fui y ahora que volví vi el tremendo cambio. Cuando una está afuera se da cuenta y se puede percatar con más objetividad, creo yo, de que hay tremendos cambios y que hay muchas cosas que ya no existen. Incluso hasta las colaciones de los niños. En esa época cuando yo estaba, era el membrillo en la época de marzo. Empezaban los damasquitos, los choclos. ¿Se acuerdan?, la quinoa dilatada como dulce. Traían rosquete en la época de noviembre. Claro, ahora no. Traen yogurt, yogurt es lo más sano que traen, papas fritas. Eso yo lo veía 10 años atrás y ahora no. Ahora todo es chatarra. Traían esos como fideos dulces que eran de acá, los pululos. Eran cosas que la gente consumía, no te puedes olvidar que habian intercambios [trueques de productos]" (Profesora 2, 2008).

Los discursos sobre ese "pasado que no volverá" no dejan de llamar la atención por cuanto un grupo de profesores parece extrañarse de que la economía tradicional atacameña, la alimentación tradicional y otras costumbres (los regalos, el trueque) hayan cambiado. Una extrañeza que parece desconocer, o al menos no aquilatar en su justa medida, el hecho que las comunidades atacameñas llevan décadas de inserción, desigual por cierto, dentro de la economía capitalista que caracteriza al país (Gundermann 2004). Ya sea en la relación mercantil sobre el trabajo productivo en los ayllu agrícolas, ya sea en la inserción de mano de obra en los sectores mineros y turísticos, o en la emergente ocupación de puestos de trabajo en oficinas municipales o servicios estatales, ha sido la propia escuela uno de los más efectivos promotores de esta inserción en la economía neoliberal que marca al país (Chiodi y Bahamondes 2001). Pero esa "extrañeza" no sorprende, pues aunque los dispositivos de homogenización del Estado han sido eficientes para efectuar una política monocultural, lo han hecho partiendo de la base de que existe una otredad, diferenciable claramente, que debe ser incorporada a la nación. De este modo, aunque históricamente la educación pública ha puesto el horizonte en que las poblaciones indígenas se eduquen en las escuelas para integrarse a la nación, si ahora se perciben cambios en sus relaciones sociales o económicas, la institución escolar lo asume como una "pérdida de sus tradiciones". 
En un sentido similar, los alumnos de Toconao son categorizados por una parte como descendientes de una cultura atacameña, pero por otra parte son considerados "chilenos, como todos nosotros". Esa categorización doble y en apariencia contradictoria, es en realidad complementaria. Desde el punto de vista en que esa pertenencia étnica es vista como residual, como mantenimiento de algunos rasgos: ascendencia, apellidos, o pertenencia a una familia con "visibilidad étnica" que participe en actividades, se complementa con la mirada que señala "los chicos son chilenos, se visten igual, escuchan reggeaton, juegan Nintendo y ven monos [dibujos animados] japoneses". Lo que además refuerzan con la referencia a los cambios alimentarios en la sociedad atacameña (Leyton 2010).

Es de hecho confusa esa asociación con lo chileno al mencionar elementos culturales, símbolos que más que chilenos pueden considerarse occidentales cuando no globales por completo. Además, no deja de ser curiosa esa mención de rasgos, "etiquetas culturales" que se juegan en un nivel de cultura juvenil.

En consonancia con la construcción que la institución escolar realiza sobre las identidades atacameña y chilena como entidades claramente distinguibles y diferenciables, se hace posible ese proceso homogeneizante que concede una "naturaleza de compartimientos estancos" a las identidades, y también que confunde cultura con identidad, y con etnia.

¿No se pone en cuestión con esto la presencia en la escuela de sujetos interculturales en el sentido dado por García Canclini?

"Más mestizajes étnicos y sincretismos religiosos que en cualquier época, nuevas formas de hibridación entre lo tradicional y lo moderno, lo culto y lo popular, entre músicas e imágenes de culturas alejadas, nos vuelven a todos sujetos interculturales" (2006: 162).

Niños y jóvenes que toman elementos y formas de relacionarse de distintas tradiciones, de "constricciones múltiples", siguiendo a Lahire (2007), que también plantea la idea de una subjetividad plural, no monolítica ni unidimensional.
Llegado a este punto se produce una sugerente paradoja, si la escuela quiere enseñar interculturalidad lo hace negando la existencia de sujetos interculturales. Pues su modo de procesar las culturas es diferenciándolas, conceptualizándolas con límites claramente establecidos sin trabajar sobre las subjetividades y las distintas trayectorias presentes en la escuela.

"[...] la necesidad de hablar de sujetos interculturales, o sea entender la interculturalidad amplia, propia de un mundo globalizado, como un factor constituyente, decisivo, en la configuración actual de la subjetividad" (García Canclini 2006: 160).

Ahora bien, los discursos docentes sobre el rescate cultural también posan su mirada sobre el quehacer de la comunidad. Directivos y profesores de la escuela son bastante críticos con la comunidad de Toconao, y con la comunidad licanantay en general. Pues tienden a representar la cultura licanantay como algo que está en proceso de disolución, aun cuando un par de docentes plantean que se mantiene vital realizando rituales y viviendo a un ritmo distinto en los ayllu más aislados ${ }^{10}$. Dicha diferencia puede estar dada porque aquellas profesoras que defienden esa "vitalidad" han vivido por décadas en la comuna de San Pedro de Atacama: "Hay algunas personas que todavía luchan por conservar lo que queda, pero es lo que queda. No es igual, [el] florecimiento [de la cultura] es imposible" (Profesora 2).

En esa apelación a la diferencia que marca el trabajo de EIB surge también la referencia al pasado histórico como una marca de identidad que se traza sobre lo licanantay. Entonces no es casual que relacionen elementos tradicionales como señas de identidad y de reconocimiento. En esta línea el tema de la lengua kunza no solo es una complicación para los profesores al trabajar "interculturalbilingüe", sino también un tema que para ellos habla de la pérdida histórica.

"Estoy hablando del año 58 cuando Grete Mostny, una investigadora, vino a hacer un estudio bien acabado y se encontró con que no había más, y lo que había de etnia kunza, o de dialecto

\footnotetext{
${ }^{10}$ Dentro de esos ritos se menciona la "limpia de canales", "el floreamiento de animales" que también se dan en Toconao, pero también otros que aún persisten en las localidades signadas como "más auténticas".
} 
kunza estaba prácticamente muerto. Y lo que había en los cantos, porque no había hablantes de kunza en la comuna, eran solo meras repeticiones de lo que alguna vez aprendieron. Algunas cosas se conocían como vocablos y esas palabras se rescataron. Pero por ejemplo, en los cantos de las mingas, de las limpias de canal hay canciones que unos repiten por repetir, y porque se han ido traspasando en el tiempo a las personas que en estos momentos lideran ese tipo de festividades. [...] Hay algunas palabras que son identificables, por ejemplo, en canciones como el Talatur nombra a los cerros, por lo tanto uno a los cerros los identifica, pero en el sentido de las estrofas ahi sí que no hay mucha traducción" (Jefe UTP, Escuela Toconao, 2008).

Las implicancias de relacionar pérdida de la lengua con pérdida cultural son variadas; por una parte, se homologa cultura y lengua en un sentido similar al que adopta el nacionalismo con el lema "una nación, una lengua, un territorio" (Dietz 2003), y por otra, marca a fuego la noción de una cultura incompleta y en deterioro. Esa representación probablemente sirve también para poner en duda desde las percepciones de los profesores las posibilidades de "enseñar interculturalidad". Este discurso en parte también se refuerza por las estrategias de las organizaciones indígenas y una parte importante de las comunidades atacameñas por situar la cuestión de la lengua y el bilingüismo como una demanda simbólica de reconocimiento cultural.

"¿Por qué no pueden hablar en kunza, ustedes? dice la profesora. 'Porque vinieron los españoles y les cortaron la lengua' responde una niña. 'A ver Marcos, tú sabes'. El aludido complementa... 'no podemos hablar kunza porque se perdió nuestra lengua. Un murmullo recorre la sala pues todos los niños hablan a la vez. 'Escuchen bien, Marcos dice que no pueden hablar kunza porque su lengua se perdió... Entre las razones que se dan y los libros que han llegado a las escuelas, y que yo estuve leyendo el primer año que estuve aquí, se decía que a los atacameños que pillaban hablando su dialecto, o su lenguaje, les cortaban la lengua. 'ïPor qué?!' preguntan un par de niños asombrados. 'Porque había que evangelizarlos, había que volverlos católicos. $Y$ como los españoles no entendian el lenguaje de ellos, entonces empezaron a cortarles la lengua, y se fue perdiendo el idioma" (Diario de campo, clase de "Patrimonio Cultural", $2^{\circ}$ Básico, junio 2008).

La respuesta de la primera niña es brutal: "porque vinieron los españoles y les cortaron la lengua". Lo que podría entenderse como una frase en sentido figurado [les cortaron el idioma] es representada como literal. Rememora el castigo de los conquistadores españoles a los licanantay que hablaban su lengua para obligarlos a hablar castellano. En este punto emergen los cruces entre la memoria y el imaginario de la comunidad, y la verdad legitimada por los textos, cruces que reconstruyen, esta vez complementariamente, una historia de conquista y conflictos donde se profundizan las tensiones entre hegemonía y subalternidad.

De este modo, mientras la profesora casada con un atacameño asocia ese castigo con los procesos de evangelización católica y con que los conquistadores "no entendían" el idioma de los licanantay, es la educadora tradicional quien va más allá y entrega en su entrevista una mirada, si se quiere, más política:

"Los atacameños fueron muy pacíficos. En cambio los mapuche se mantuvieron peleando. Los españoles les cortaban la lengua porque no querían que hablaran entre ellos sin saber que decían" (Educadora tradicional 2008).

Su explicación muestra un tinte más político por cuanto presupone que el verdadero objetivo de los conquistadores era imposibilitar la comunicación al interior de la sociedad atacameña. Conversaciones que serían vedadas a sus oídos con el riesgo potencial de convertirse en canal de conspiración y resistencia a la ocupación. De igual forma, su referencia a que "los atacameños fueron muy pacíficos", además de plantearse como contrapuesta a la resistencia mapuche, también reviste probablemente una crítica soterrada de la educadora tradicional a su propia comunidad de porqué no se resistió más en ese momento.

"La educadora tradicional parada en el centro de la sala, comienza por preguntarles a los niños el significado de algunas palabras en kunza. 'Quées sairi?', los niños se quedan en silencio unos momentos pero una alumna levanta la voz: 'es lluvia.' 'Bien' le dice la educadora tradicional. En un rincón de la sala la profesora jefe revisa el libro de clases y de vez en cuando levanta la vista para seguir la participación de los alumnos. 'Y cómo se dice Luna?', pregunta nuevamente la educadora... 'camur', dice un niño. En ese momento la profesora interviene y pregunta 'álguien puede hacer una oración con una palabra kunza?' El silencio es total en la sala, la educadora tradicional sonríe y se 
muestra expectante: 'A ver tú, Pablo, haz una oración con camur'. El niño piensa un rato y responde: 'La camur es linda"' (Diario de campo, clase de "Patrimonio Cultural", $2^{\circ}$ Básico, junio 2008).

La lengua kunza queda supeditada a ejercicios en la clase de patrimonio o de computación, donde se usan las palabras kunza que han persistido y se integran a resúmenes en el computador, armar frases en castellano con algún termino kunza, o referencias muy precisas sobre nombrar en lengua kunza elementos del entorno geográfico licanantay. Pero siempre como integración minoritaria, a nivel de glosario, de algún término dentro de un contexto textual u oral mayoritariamente castellano.

Este mecanismo pedagógico que descontextualiza la lengua, también es planteado por Szulc (2009) para el caso de la educación intercultural bilingüe en Neuquén, donde el mapudungun es descontextualizado para ser enseñado por la escuela en función del idioma español y acorde a la lógica escolar. Para el caso atacameño dicha práctica pedagógica está agudizada por la reconocida desaparición de la lengua kunza. Por tanto, los vocablos y palabras que fragmentariamente son recogidos, son subsumidos y asimilados por el idioma español.

\section{Lo intercultural como patrimonialización de la cultura}

Ahora bien, si un objetivo del programa intercultural de la escuela es el rescate cultural, cabe preguntarse: icómo la escuela realiza este rescate cultural? A modo de respuesta podemos plantear que el trabajo en la escuela sobre lo intercultural se basa en un criterio patrimonializante de la cultura (en términos de pérdida/rescate) por parte de los profesores, y donde la educadora tradicional también interviene con nociones similares sobre la cultura, pero construida desde su conocimiento local.

"La cultura atacameña está desapareciendo. Antes había más rescate cultural, costumbres, tradiciones, pero ahora prácticamente no se ve. Y si hay algo, se cubre con la jarana, con la fiesta y otro tipo de cosas" (Profesora 7, 2008).

"La limpia de canales ya no se hace, cuando se limpiaba el tranque ya no se hace. Bueno, se hace pero hay que pagar, ahora ya no hay minga ${ }^{11}$. Y la minga era lo que sostenía estas culturas [...]. Está [la fiesta de] San Juan pero es celebración, me entiendes, pero lo importante ya no existe" (Profesora 2, 2008).

Así se va desarrollando desde la mirada de los docentes una noción de cultura como conjunto de elementos (lengua, tradición, vestimenta, ritualidad, prácticas económicas), que en la medida de la pérdida de esos elementos caracterizadores, deviene en pérdida de la cultura donde el todo se fragmenta y pierde su condición "original" y "auténtica".

Esta definición que se construye desde la lógica escolar, destaca por su esencialismo y cosificación del concepto de cultura en tanto agregado de elementos, en un sentido similar al criticado por Appadurai al distinguir la cultura como sustantivo de lo cultural como construcción de la diferencia. Idea que retoma y analiza García Canclini para elaborar una definición de lo cultural estrechamente ligada a lo intercultural:

"Al proponernos estudiar lo cultural, abarcamos el conjunto de procesos a través de los cuales dos o más grupos representan e intuyen imaginariamente lo social, conciben y gestionan las relaciones con otros, o sea las diferencias, ordenan su dispersión y su inconmensurabilidad mediante una delimitación que fluctúa entre el orden que hace posible el funcionamiento de la sociedad, las zonas de disputa (local y global) y los actores que la abren a lo posible" (2006: 40).

Lo anterior nos permite reflexionar sobre cómo las representaciones que construye la escuela sobre el rescate cultural se sustentan en su definición esencializada de la cultura para activar diversos mecanismos de patrimonialización, de tal manera de emerger como contracara complementaria a esos discursos sobre cultura que se pierde y cultura que se rescata.

En ese sentido, la definición de cultura que desarrollan la mayoría de los docentes se sustenta, a su juicio, por lo que han visto y vivido a diario en la localidad durante años de trabajo. Una legitimación para sus opiniones amparadas en una suerte de autoridad del "estar alli"

\footnotetext{
${ }^{11}$ Trabajo comunitario asociado a alguna actividad productiva, donde la mano de obra ofrece su fuerza de trabajo de manera no asalariada y con una funcionalidad simbólica de cohesión social.
} 
en un sentido casi geertziano. Pero esa definición de cultura que podría quedar reducida a sus percepciones individuales reviste importancia en tanto se estructura como un modo de encarar la pedagogía frente a los alumnos.

Ese modo de encarar la pedagogía entrelaza representaciones, discursos, prácticas y valoraciones que "se hacen carne" a través de distintos dispositivos que se articulan entre sí. Así, detallaremos tres dispositivos que operan de manera interrelacionada en la patrimonialización de la cultura observada en el contexto de esta escuela, y que creemos, grafican la presencia de un terreno en disputa por las representaciones sobre lo licanantay, predefinidas por ese enfoque patrimonializante.

Primero, el dispositivo de homogeneización-cristalización de lo representado como cultura licanantay. Segundo, el dispositivo de resignificación de prácticas cotidianas de la comunidad según su "tradicionalismo". Tercero, las activaciones patrimoniales.

La homogeneización-cristalización de lo licanantay. La escuela patrimonializa lo intercultural reproduciendo un habitus escolar que es el de entregar una verdad homogénea a los alumnos. Por eso, aunque los docentes trabajen sobre la diferencia cultural lo harán entregando una mirada homogénea. En ese sentido, parece persistir una mirada a-histórica, donde la cultura se aprecia como una fotografía realizada en un momento particular pero que luego es idealizado como "originalidad constante". Algo que "es" la cultura y que "debe" seguir siendo, para ser reconocida como cultura. Mientras, por otra parte, se desvaloriza lo festivo como sinónimo de desorden ("Y si hay algo, se cubre con la jarana, con la fiesta y otro tipo de cosas"), sin considerar su importancia ritual ni comunitaria.

Siguiendo a Dietz (2003), para profundizar en la noción de interculturalidad y educación hay que debatir en principio el papel homogeneizador de la escuela y sus procedimientos de internalización de estructuras hegemónicas del poder y de la construcción y codificación de una "cultura nacional". Es importante cuando se señala que lo que la escuela no puede homogenizar acaba diferenciándolo y segregándolo.
Ahora bien, en el proceso de homogeneización cultural se patrimonializa la cultura, construyendo desde la escuela un modelo de cultura que dista de estar conectada a los modos de vida y de relación de los sujetos, pero que pese a eso se representa con un principio de realidad.

Esta noción monocorde y modélica de la cultura, y de las etnias, confundidas como una sola "cosa" en el lenguaje de la institución educativa, anula y oculta, por ejemplo, las diferencias intra-étnicas y las diversas formas de vivir una cultura. Del mismo modo en que la escuela dificulta el ver la diversidad intra-étnica tampoco ve, ni se interesa en ver, la interculturalidad como proceso, sino que la presenta como patrimonialización y rescate de elementos característicos de las culturas de minorías. No en vano la denominación para la clase donde se muestra, supuestamente, la cultura licanantay es "Patrimonio Cultural".

"La otra vez les pregunté a qué etnia pertenecían y no sabían... ahora saben: 'atacameños', dice la profesora dirigiéndose al curso, ¿Quéson ustedes entonces?...' 'atacameños' gritan los niños. 'Qué otro nombre tienen?' pregunta la profesora... 'licanantay' vuelve a gritar un grupo de niños. Entre ellos se escucha la voz de uno que dice 'chileno'. La profesora se ríe con la intervención del chico... 'chileno', repite la profesora" (Diario de campo, clase de "Patrimonio Cultural", $2^{\circ}$ Básico, junio 2008).

Significativo es que en el desarrollo de esta dinámica, la profesora homogeniza a todo el curso como "atacameño", aun cuando hay niños y niñas, hijos de trabajadores que han llegado de otros lugares de Chile. Para ella todos son atacameños, incluso la voz de un alumno que apela a ser "chileno" es irónicamente puesta en cuestión por la profesora, que no se detiene, por ejemplo, a discutir si se puede ser chileno y atacameño a la vez.

Tampoco se detiene a comentar que no todos los niños son toconares. De hecho hay alumnos de otras localidades que residen de lunes a viernes en el internado de la escuela. Esa diversidad intra-grupal no es complejizada, ni discutida, ni mencionada (itampoco percibida?) en el aula. Obviamente, no es un problema particular de la profesora, más bien es la fuerza con que opera el dispositivo homogeneizador de la institución escolar, que parece tener muy claro que existen diferencias, "fronteras 
étnicas" (Barth 1982) que permiten diferenciar dos culturas, y a la vez, homogenizar hacia dentro de cada una.

Sobre esa línea de lo unívoco, podemos emplear la crítica en relación al discurso experto y a la posición de la educación intercultural en el centro de una institución homogeneizadora (Franzé 2003). Se reproduce a través de la escuela la imagen de la cultura como algo único y sólido, que se suele representar con el isomorfismo cultura-lengua. La simplificación de la cultura y de lo permitido como valorable adquiere entonces un carácter de inmutabilidad y de centralidad en el proceso de asignar valor a la diferencia.

“'Anotaron la tarea', dice la profesora. 'Si', dicen a coro los chicos. 'No se les va a olvidar nunca que son atacameños?' continúa preguntando la profesora al curso. "Sí", "no" son las respuestas que gritan los niños. "Y se van a sentir orgullosos de ser atacameños?' vuelve a preguntar la profesora, 'si' gritan los niños. 'Porque yo he sabido que varios niños que se van de aquí a estudiar a Calama... [Dicen] 'no, yo no soy atacameño, yo no vivo en el interior. Ustedes deben sentirse orgullosos de ser atacameños. Ustedes son atacameños, son de las pocas etnias que quedan en Chile"' (Diario de campo, clase de "Patrimonio Cultural", $2^{\circ}$ Básico, junio 2008).

Seguimos con este ejemplo, por cuanto condensa esa necesidad de la institución escolar de definir identidades. Aquí aparece con fuerza uno de los motivos principales para levantar todo el proyecto intercultural y que no es otra cosa que fortalecer la autoestima y el orgullo de pertenecer a una etnia. Por contrapartida, como comentó una profesora, la idea es "darles una especie de vacuna que los defienda de la discriminación”" (Profesora 4, 2008). De algún modo, lo que está presente aquí es que asumiendo que al ir a estudiar a la ciudad de $\mathrm{Ca}$ lama los van a discriminar por ser indígenas, y por venir del interior, los alumnos deben llevar una identidad "orgullosa". Entonces curiosamente, el problema de la discriminación pasa a ser responsabilidad de los alumnos que no tienen "orgullo" por su identidad, y no problema de la sociedad. Ese desplazamiento del problema de la discriminación si bien se explica porque la escuela es el espacio de control de estos docentes, no debiera enmascarar una crítica o al menos la comprensión de que un problema como la discriminación o el racismo involucran a toda la sociedad chilena. Esa perspectiva de algún modo muestra el carácter acotado de lo intercultural como relevante para las escuelas en contexto indígena, pero no para todo el sistema escolar.

Ahora bien, volviendo a la mirada de que lo intercultural se trabaja en función de repertorios o conjuntos de elementos representativos de cada cultura, se plantea la pregunta de qué se incorpora como elemento significativo de cada cultura, y qué se deja afuera. En síntesis, cómo se administra desde la institución escolar la dinámica inclusión-exclusión en referencia a lo representativo de una cultura.

En ese sentido, es relevante considerar la presencia en el aula de la educadora tradicional que representa a su comunidad, y que además, al tener nexos con la asociación indígena, probablemente construya su mirada y su praxis como una reconstrucción de lo licanantay sobre lo reconocible y representable en las coordenadas de interacción de lo indígena con lo chileno.

"Este baile lo recuperó mi tía con el maestro Mondaca y llevaba años desaparecido. Si no fuera por ellos ya no estaría. Entonces eso es lo que trato de mostrarle a los niños, que esto lo tienen que querer y cuidar para que no desaparezca" (Educadora tradicional 2008).

De un modo similar, también la comunidad atacameña elabora estrategias de representación sobre su tradición, sobre su pasado, sobre su cultura. Estrategias que van de la mano con esa "temporalización" a la que alude Dietz como parte de las estrategias del nacionalismo nacionalizante pero también de la etnicidad particularizante (Dietz 2003: 98). Conceptualizar la memoria y la tradición como una representación central de la identidad para disputarle al Estado nación la reinvención de su pasado. De alguna manera, valga el juego de palabras, reapropiarse de lo propio.

\section{La legitimación escolar de las prácticas comunitarias.}

"Esto es un cuero de suri [ñandú], dice la educadora mientras saca de una mochila la piel de un ave bastante grande, de la que se conserva toda su forma, cabeza, alas, cuerpo. La educadora lo coloca sobre su espalda, y queda cubierta por ella. 'La mataron', dice un niño. La educadora no hace comentarios sobre eso y pasa a explicar para qué sirve: 'Uno se pone esto para bailar'. Una niña 
le dice: 'ipor qué no baila ahora?'. 'Si!!!!' se suma al pedido el resto del curso. La educadora asiente y les pide a los niños que van a bailar con ella a la semana siguiente que la acompañen. Los cuatro niños que se levantan (tres niños y una niña) se colocan en dos filas que comienzan a danzar hacia delante y hacia atrás mientras la educadora con la piel de suri sobre sus hombros baila entre ellos como cuidándolos"12 (Diario de campo, clase de "Patrimonio Cultural", $2^{\circ}$ Básico, junio 2008).

La re-elaboración de la memoria se transforma también en reproducción social mediada por la lógica escolar que, por una parte, explica la función de los materiales relacionados con un ritual, pero que también al motivar la dramatización de ese ritual, los revitaliza con su uso social, aunque legitimado por la escuela que lo reconoce como un "ritual tradicional". Es una aproximación al patrimonio como folclore, y en tanto danza, se integra al conjunto de elementos que para la escuela son parte de la cultura licanantay.

La escuela emerge, entonces, como un espacio de burocracia. En tanto forma parte de las políticas educativas del Estado, deviene en una institución especializada en procesar cultura, una cultura "legítima", formalizadora y de tinte burocrático, realizando su mecanismo de enseñanza y aprendizaje sobre nociones descentradas del aquí y ahora (Díaz de Rada 1996).

Siguiendo a Díaz de Rada, la institución educativa procesa el saber como una segmentación de conocimientos. Y frente a la noción de cultura como proceso diverso confronta una mirada sobre lo particular y lo descontextualizado. De hecho, en esta burocratización de las reglas del saber, la escuela opera sustancializando la cultura, transmitida ya no como proceso de relaciones sino como reificación. En ese sentido funciona lo que este autor llama la "distalización burocrática del saber", que viene a ser el mecanismo por el cual la escuela entrega al alumno una versión de la cultura pero desconectada y distante del sujeto.

Por ejemplo, la festividad de San Juan Bautista, patrono de Toconao, coincide también con el año nuevo indígena, por lo tanto las clases de "Patrimonio Cultural"

\footnotetext{
${ }^{12}$ En este baile, a grandes rasgos, se representa a un ave que cuida de sus crías.
}

como las de "Tecnología" tenían referencias explícitas a estas celebraciones. En el curso de "Patrimonio Cultural", la educadora tradicional les cuenta qué ocurre en esos días:

"Se nos acerca el 24 de junio, donde se hace el floreamiento de animales en honor a San Juan Bautista, que era pastor. ¿Ustedes saben qué es el floreamiento?, pregunta la profesora. Los niños miran en silencio. La educadora saca de un bolso un cordel de lana tejida en varios colores, 'esto se coloca en la oreja de la llama, en las más chiquitas se coloca en el cuello [...]. La noche del 23 se baila el Catimbano para San Juan'. La educadora saca de una bolsa que trae, una máscara de yeso. Así son las máscaras del Catimbano. Los que van a bailar conmigo, cya tienen su máscara?' Tres niños contestan que sí, 'yo también la tengo' dice uno de ellos" (Diario de campo, clase de "Patrimonio Cultural", $2^{\circ}$ Básico, junio 2008).

Ahora bien, si antes se hablaba de la referencia al pasado, ahora cabe la mención a lo que desde la escuela, sobre todo reforzado por la educadora tradicional, se destaca como tradiciones que perduran en el presente, ya sean festividades locales de carácter sincrético, o instancias de reunión comunitaria.

La educadora tradicional aprovecha la coincidencia con la festividad, el currículo emergente, y les explica a los niños el ritual que se desarrollaría en una semana. Más de la mitad del curso parece desconocer lo que es el floreamiento $^{13}$, sin embargo la explicación de la educadora es acotada y se remite a mostrar los materiales más relevantes para llevar a cabo parte del ritual. Así enseña los cordeles que atarán a las llamas, o las máscaras que utilizarán para el baile en la noche anterior a San Juan. La educadora tradicional no solo exhibe esos materiales, sino que también busca contextualizar su uso, aunque no pueda abstraerse de nociones de patrimonialización de la cultura.

La institución escolar opera como un espacio legitimador de la otredad. Lo que es válido para la escuela de las prácticas de la comunidad emergerá como demostración

${ }^{13}$ El floreamiento es una ceremonia donde la comunidad se reúne para colocar hilos de lana de colores a sus animales (generalmente llamas), que simulan flores, para embellecer y homenajear uno de los principales recursos económicos tradicionales de la comunidad. 
del mantenimiento de una tradición. Otro tipo de bailes, otro tipo de música no decodificado por la escuela como continuidad del pasado es deslegitimado.

Por ejemplo, las fiestas que en distintas fechas se desarrollan en la comuna son vistas con esta mirada oscilante. El hecho de que estas celebraciones siempre cuenten con una importante cantidad de alcohol, gatilla en los profesores una cercanía-distancia con estas fiestas. Por una parte las valoran como continuidad de una tradición atacameña "de las pocas que se mantienen" (Profesora 2, 2008), pero por otra parte, las miran con recelo pues señalan que "mucha de la gente que va, va a puro tomar" (Profesora 5, 2008). Esta misma mirada de recelo aplican los profesores que, al mencionar la fiesta de San Pedro de Atacama como tradición que se mantiene, la desvalorizan al decir que "se llena porque la gente va a escuchar los grupos de sound [música fiestera] que trae la Municipalidad".

Activación del patrimonio desde la escuela. Desde otra posición, el trabajo de Montenegro (2010, 2012) sobre los procesos de activación del patrimonio en las escuelas de Jujuy, si bien se inscribe en proyectos con carácter de investigación-acción, muestra con claridad la emergencia de un tipo de conceptualización en educación intercultural que sitúa el aspecto patrimonial como un nodo sobre el que confluye escuela y comunidad.

Para el caso que nos ocupa, las actividades pedagógicas donde hay mayor participación de alumnos son aquellas referidas a ritos y festividades locales. Por ejemplo, una serie de clases de "Patrimonio Cultural" tuvo como objetivo preparar a los alumnos para el baile Catimbano. Dicho baile se representó en la iglesia de Toconao en la noche de víspera de la festividad de San Juan, donde participó un grupo de alumnos, la educadora tradicional y personas de la comunidad. Incluso un par de profesoras que tienen buena relación con la comunidad asistieron a la iglesia.

De este modo, la incorporación de los niños en una actividad comunitaria preparada en el aula, habla de esos entrecruzamientos que operan sobre un espacio en pugna, el de la definición y representación de lo patrimonial. Donde si bien la escuela patrimonializa homogeneizando y opera otorgando (o negando) legitimidad a las prácticas de la comunidad, también permite espacios, como el obtenido por la educadora tradicional, para re-actualizar prácticas comunitarias e integrarlo a lo pedagógico, estimulando esas "activaciones patrimoniales" a las que se refiere Montenegro (2010, 2012).

Surge esa re-valorización de las tradiciones desde una mirada etnicista y enmarcado en un proceso de etnogénesis que supera con creces el espacio escolar y que tiene que ver también con los procesos de re-etnificación del mundo indígena chileno iniciados en los años 90 , y que se sustentan en ese complejo juego entre Estado, economía neoliberal y reivindicaciones étnicas. A modo de ejemplo, el tema del turismo en San Pedro de Atacama ha hecho confluir patrimonio, territorio y economía neoliberal con la promesa de posibilitar la autogestión de los recursos y patrimonios de parte de las distintas asociaciones indígenas. En este sentido, Toconao aun cuando (por ahora) tiene un rol secundario en esas dinámicas, de todos modos forma parte de los circuitos turísticos especialmente por su plaza, su iglesia, la construcción característica de sus casas en piedra y la quebrada de Jere. De tal forma que el turista pasa a ser un sujeto más que transita por sus calles.

"La educadora comenta al curso el baile del Chara-Chara es nupcial. Representa un homenaje a los novios.' A un costado de la sala un niño toca el acordeón y otro un bombo. Los asientos han sido empujados hacia las paredes para dejar libre un área amplia en el centro de la sala. Los demás compañeros se ordenan en dos filas, una de hombres y otra de mujeres que danzan haciendo ademán de dejarles ofrendas a los novios que están arrodillados frente a los danzantes. La profesora que está sentada al lado mío me comenta lo bien que ejecutan los instrumentos los alumnos [...]" (Diario de campo, clase de "Patrimonio Cultural", $4^{\circ}$ Básico, junio 2008).

Todos los alumnos participan de la clase, y la profesora jefe o tutora, que ya ha manifestado en distintas ocasiones no estar de acuerdo con la opinión generalizada de los otros profesores sobre la "progresiva muerte" de lo licanantay, me señala que el problema de los otros profesores es que no conocen a la comunidad ni han vivido tanto tiempo en la zona. Además, dice sentirse "atacameña" pues lleva mucho tiempo casada con uno.

Esta mirada, si bien minoritaria, sirve para poner en perspectiva los distintos lugares simbólicos desde don- 
de los profesores construyen sus juicios y realizan sus prácticas. Y cómo sus historias personales van condicionando su cercanía o distancia, confianza o recelo en el trabajo con la EIB.

Otro tipo de dinámica escolar sobre la noción de patrimonio se desarrolló en la clase de “Tecnología”. La profesora les pidió a los alumnos que realizaran un Power Point que representase el altar de ofrendas al santo.

Los distintos grupos de alumnos elaboraron un tipo de afiche bastante similar entre ellos. En su parte central aparecía la figura de un santo, representado como un hombre de edad avanzada con barba y túnica, rodeado de figuras de vegetales o productos que han podido "cortar y pegar" con las funcionalidades del Power Point, o bien en archivos anteriores guardados en el computador. Figuras que representan las donaciones de la comunidad al santo para agradecerle buenas cosechas, el aumento de los rebaños o alguna promesa cumplida el año anterior. Asimismo, a un costado del afiche los alumnos ponen en palabras una descripción de lo que lleva el altar y que no han logrado plasmar en figuras.

Esta actividad realizada en la sala de computación fue hecha al día siguiente de la festividad y no se basaba en búsqueda de información. Por el contrario, no pasaba de ser un ejercicio que como la misma profesora confesaba, podía realizarse en un cuaderno o en una hoja. Con ese enfoque, la potencialidad de esta práctica quedaba reducida y limitada a ejercitar el uso del Power Point y a aprovechar como tema la coincidencia con la festividad.

\section{* La Relación no resuelta entre escuela Y COMUNIDAD}

\section{“Por qué la escuela debe enseñar lo que la familia no enseña?"}

La expresión pertenece al director de la escuela, y condensa de buena manera la posición de los profesores sobre el hecho, que ellos entienden como sobreexigencia, de tener que rescatar conocimientos de una cultura que los propios sujetos de esa cultura no han mantenido ni reproducido.
Esa posición habla de una continuidad en el discurso docente, no solo en Toconao sino en muchas partes de Chile, de que la escuela acaba siendo sobreexigida en sus capacidades. Teniendo que salir a cubrir a la familia en todos aquellos aspectos conflictivos: drogas, sexualidad, violencia, valores, entre otros (Catalán y Egaña 2004). A lo cual se agrega el hacer rescate cultural, que es como la mayoría de los profesores de la escuela entiende la EIB.

En ese sentido no extraña que los profesores se rebelen a la obligatoriedad de incorporar contenidos contextualizados culturalmente a sus clases, pues a esa obligatoriedad también le agregan el sentir que la familia no se da el tiempo de enseñarle a los niños y jóvenes lo relativo a su ascendencia étnica.

Lo que la escuela ve como apatía en la familia no solo lo aprecian a la hora de mencionar los contenidos "atacameños", sino también lo que para ellos es un progresivo desdén de la familia en apoyar el repaso de los contenidos por los alumnos en sus casas.

Para finalizar, los profesores en sus menciones sobre la comunidad, y específicamente sobre los padres de los alumnos, también incorporan como razón de su escaso interés en la EIB, que para aquellos "lo intercultural no es un tema" (Profesora 6, 2008), y que "ni a los papás, ni a los alumnos les interesa mucho" (Profesora 3, 2008). Es más, agregan que a muchos padres les interesa que sus hijos aprendan inglés antes que kunza. Lo que de algún modo se conecta con una lectura de los padres sobre qué pedir a la escuela en tanto institución que ofrece una promesa de obtener bienes simbólicos, determinados conocimientos, que tendrán valor futuro en el mercado laboral, al cual apuntan los conocimientos y certificados que entrega.

Esto se relaciona también con el SIMCE ${ }^{14}$ y las evaluaciones, como un horizonte burocrático donde sí se juega la legitimidad de la escuela en el sistema escolar y donde la

\footnotetext{
${ }^{14}$ Sistema de Medición de Calidad de la Educación. Es una prueba estandarizada a nivel nacional que se aplica en $4^{\circ}$ Básico, $8^{\circ}$ Básico y $2^{\circ}$ Medio. Mide contenidos de lenguaje y comunicación, matemáticas, comprensión del medio social y cultural, y comprensión del medio natural.
} 
interculturalidad como potencial contenido pedagógico, no tendría el peso específico de otros conocimientos más legitimados en el currículo escolar.

Lo anterior se relaciona también con la falta de pertinencia cultural que los docentes observan en los materiales y metodologías entregadas por el Ministerio de Educación y que ellos caracterizan como fuertemente influenciada por lo mapuche. Esa "mapuchización" de la educación intercultural en Chile también es destacada por otros autores (Hernández 2004; Hevia 2005), que ven la EIB como un modelo de lo intercultural desarrollado sobre la base de las iniciativas pedagógicas realizadas en escuelas rurales en contexto mapuche.

\section{Interculturalidad, ¿para qué?}

"Acá [en la comunidad] la interculturalidad no la necesitan. Es para Calama que la necesitan, cuando salen de acá y se encuentran con los 'lobos' [alumnos del liceo que los discriminan]. Acá ellos están tranquilos, allá ellos van a necesitar ser fuertes" (Director 2008).

En un sentido similar, aparece la mención a vivir en el "interior" como una categoría negativa y objeto de discriminación basado en la diferencia rural-urbano. Entendiendo que los alumnos de la ciudad tendrán una imagen negativa de la ruralidad, y a la cual asociarán a los alumnos provenientes de Toconao.

La referencia que hace el director de la escuela sobre los alumnos "lobos" que amenazarían a los buenos alumnos que han salido de la escuela y la comunidad, engloba también la imagen de lo local, que muy acorde con la dimensión patrimonial asociada a la cultura, marca un espacio donde no existiría el peligro de discriminación, lo cual sí se daría en una ciudad donde los jóvenes llegarían como minoría.

La referencia a Calama, es porque cuando los alumnos terminan $8^{\circ}$ Básico, las familias prefieren mandarlos a esta ciudad, el núcleo urbano más cercano de San Pedro de Atacama, pese a que hay liceos de enseñanza media en la comuna, porque suponen que ahí es mejor la educación. Y al llegar allá, se enfrentan a una posición de ser recién llegados desde una localidad identificada como indígena.
Esa concepción de lo intercultural como refuerzo positivo de las minorías deja sin desarrollo una amplia área, y quizás igual de importante sea generar una educación de convivencia también para aquellos que creen no ser parte de esas "minorías", incluso pensándolo en términos de la globalidad de la sociedad, y en especial de la comuna de San Pedro de Atacama, que históricamente ha visto la llegada de población de distintos lugares y culturas. Así lo intercultural realmente tendría un enfoque de relacionamiento entre grupos diversos, y no solo de potenciación y sensibilización sobre la diferencia.

Desconfianzas mutuas. Tanto directivos como docentes delimitan la participación de los padres en la escuela, solamente para el reforzamiento en los hogares de los contenidos y actividades estipulados por los profesores. Se oponen a cualquier cuestionamiento de tipo pedagógico por parte de apoderados y padres. Ya sea sobre las actividades de clase, los contenidos, o cualquier cosa que para los docentes y directivos forme parte de lo exclusivamente pedagógico.

"Que no nos diga la familia cómo debemos educar" (Director 2008). Esta posición defensiva se muestra en apariencia contradictoria con la misma imagen que el director mencionaba como "escuela abierta", donde los apoderados y padres de los alumnos no tendrían ningún impedimento para ingresar a la escuela cuando quisieran hablar con los profesores o con él.

En todo caso, esta política de "puertas abiertas" también es remarcada por el director como una señal del buen quehacer de los profesores, pues el docente al saber que un apoderado puede aparecer en cualquier momento dentro de la escuela, no va a querer estar fuera del aula, y así evitará que el apoderado se pregunte "ipor qué ese profesor no está haciendo clases?" Este factor, que podría considerarse desde una perspectiva crítica como dispositivo de vigilancia y disciplinamiento del docente, también refiere a la escuela como sistema de normas para administrar confianzas y desconfianzas.

"Lo que falta es un poquito de comunicación [con la comunidad de Toconao]. Nosotros nos encontramos con que gente de la comunidad habla 'la escuela aquí, la escuela allá, para bien o para mal. Pero si tú me preguntas si ellos se han acercado a conocer nuestra visión, qué es lo que queremos, qué se va a hacer. 
Sin embargo no tienen esa intención de acercarse a la escuela, los dirigentes que se acerquen a conocer, 'queremos saber cómo está funcionando, qué ideas tienen, cuáles son sus proyecciones, para saber de qué manera podemos ayudar'. No, no se produjo esa situación que sería lo ideal. A lo mejor nos aportaría un poquito más para mejorar algunas condiciones. No me refiero a situaciones de infraestructura sino que por lo menos de preparación de nuestros niños. Entonces ahí hay como un pequeño divorcio. Justamente porque los dirigentes no están acá, los dirigentes están en Calama. Entonces cuesta que se interesen por lo de la escuelay cómo estamos trabajando" (Jefe UTP 2008).

Aun en esa dinámica, existe la idea socorrida del "buen apoderado" que se comporta según lo que la escuela espera de él (y le permite). Aquel que participa en el reforzamiento de los aprendizajes desde el hogar, que ayuda al alumno en actividades o trabajos donde el docente ha recomendado su participación, o que incluso entrega su apoyo irrestricto a las decisiones y orientaciones de la escuela.

"Hay de todo [apoderados], los que apoyan y los que no. Yo tengo buenos apoderados que me preguntan qué necesitan los niños y cómo pueden ayudar. También no dan problemas si les pido a los alumnos que vengan un sábado o domingo a practicar para el SIMCE" (Profesora 6, 2008).

"Tenemos bastantes apoderados que han sido alumnos nuestros. Que han pasado por aqui”" (Jefe UTP 2008).

Sin embargo, pese a esa buena relación con algunos apoderados, directivos y docentes de la escuela, mantienen una controlada distancia con la comunidad. Lo que señalaron algunas personas de la comunidad es que hace un par de años hubo un grupo de padres de alumnos que intentaron que el director fuera cesado de su cargo pues no les gustaba su trabajo. Pero no pudieron, y desde entonces el director ha mantenido distancia con la comunidad, y los profesores también.

Como en toda historia, hay más de una versión. Para este caso, la versión del director es que el distanciamiento con la comunidad ocurre porque antes de 2008 él le pidió a la Municipalidad un terreno para construir el internado, para que ahí vivieran los profesores, y que todo marchaba bien pero debía pasar por la autorización de la comu- nidad atacameña ${ }^{15}$, la cuál les negó el permiso porque "los profesores no son atacameños".

Ambas versiones, aunque distintas, muestran la presencia de un conflicto no resuelto entre la comunidad y la escuela, y que ha devenido en un distanciamiento que de alguna forma simboliza el tratamiento de la EIB al interior de la escuela. De este modo, parece que la escuela se cierra en sí misma, y la comunidad se mantiene afuera, y solo se relacionan para lo estrictamente necesario. Como si la consigna fuese: a la escuela lo que es de la escuela, y a la comunidad lo que es de la comunidad.

En ese sentido, la comunidad empoderada "juega el juego" de la legitimación y obtura el proyecto de interculturalidad en la escuela al no participar en ella, en parte por la postura de los directivos, y en parte por la propia decisión de las personas que pertenecen a la comunidad. De todos modos, el proyecto se va quedando sin legitimidad ni proyección. Empoderada en su relación con el Estado, la comunidad de Toconao sabe que las políticas hacia lo indígena no son nada sin los indígenas. En una relación casi especular, la comunidad niega como tantas veces fue negada.

\section{$\diamond$ Conclusiones}

La implementación de un proyecto de educación intercultural por parte de la escuela de Toconao se construye desde una compleja situación, por cuanto su tradicional papel de administración de saberes legítimos y homogéneos se ve enfrentado ahora a la misión de enseñar la interculturalidad e incluso fomentarla según las políticas del Ministerio de Educación. Compleja tarea para una institución como la escuela que durante más de un siglo neutralizó la diversidad para ayudar a crear una "cultura nacional". Si antes debía homogeneizar ahora debe trabajar con diversidad.

15 En el marco de la Ley Indígena, los terrenos catalogados como territorios con presencia de población originaria (etnias) solo pueden ser traspasados y vendidos entre indígenas, y no pueden tener propietarios no reconocidos por la ley como indígenas. Por lo tanto, cualquier figura de entrega por comodato, o permiso de uso de terrenos debe ser visada por la organización indígena tradicional que representa a esa etnia. 
Instalada esa necesidad, la escuela de Toconao centra su mirada para trabajar la diversidad sobre la base de una noción de cultura patrimonial, y desde ese lugar comprende lo licanantay como una marca identitaria pero en proceso de desaparición. Eso, porque ve la cultura como un conjunto de elementos caracterizadores que en la medida de su presencia o no, puede considerarse como más cultura o menos cultura.

Esta perspectiva de patrimonialización de la cultura condiciona el trabajo con la EIB como rescate de elementos supuestamente característicos de la cultura licanantay. Estableciendo una aproximación que muestra a la cultura distanciada de los sujetos (en este caso los alumnos), y la presenta como una entidad externa que ellos deben conocer.

En la medida que la comunidad licanantay no "conserve" su lengua kunza, según los docentes se dificulta cualquier tipo de iniciativa y trabajo en educación intercultural. En- señar cultura sin una "lengua viva" como patrimonio, les genera una perspectiva de pérdida irreparable de la condición licanantay.

Sobre la noción de la cultura como repertorio de elementos cabe la interrogante sobre cuáles de ellos se valoran y se ponen de relieve, y cuáles se ocultan, siendo precisamente la escuela quien administra esas distinciones. Lo anterior lleva a plantearse, en términos generales, si la escuela puede (y debe) ser quien recree la cultura de los alumnos, su cotidianeidad y su contexto de vida, más aún considerando que genera una distancia entre cultura y sujeto.

La clase de "Patrimonio Cultural" es emblemática a este respecto. Se refiere una y otra vez a los cuentos atacameños, la comida atacameña, el "sentirse orgulloso de ser atacameño", casi como una seña de identidad definitiva, pero a la vez como una identidad ausente, o por lo menos, en crisis.

\section{* Referencias citadas}

ÁLVAREZ, J., 2003 Ms. Currículo andino y participación social en el Norte Grande de Chile. Ponencia presentada al seminario Implementación Participativa de la Educación Intercultural Bilingüe.

ANDERSON, B., 1993. Comunidades imaginadas. Fondo de Cultura Económica, México D.F.

BARTH, F., 1982. Ethnic group and boundaries: The social organization of cultural difference. Universitetsforlaget, Oslo.

BOLADOS, P., 2006. La educación intercultural atacameña en los procesos étnicos actuales: Aproximación, análisis y comprensión de los discursos en los principales agentes que la implementan. Tesis para optar al grado de Magíster en Antropología. Instituto de Investigaciones Arqueológicas y Museo, Universidad Católica del Norte, San Pedro de Atacama.

BOURDIEU, P., 2006 [1989]. Los poderes y su reproducción. En Lecturas de antropología para educadores, H. Velasco, F. García y A. Díaz de Rada (Eds.), pp. 389-429. Editorial Trotta, Madrid.

BOURDIEU, P. y J. PASSERON, 1977. Reproduction in education, society and culture. Sage, Londres.
CAÑULEF, E. (Ed.), 1996. Hacia la interculturalidad y el bilingüismo en la educación chilena. Fundamentos y bases curriculares desde la perspectiva aymara-atacameña y mapuche. Editorial Pillan, Temuco.

1998. Introducción a la Educación Cultural Bilingüe en Chile. Serie de investigaciones 5 . Instituto de Estudios Indígenas. Universidad de La Frontera, Temuco.

CARRASCO, S., 1997. Usos y abusos del concepto de cultura. Cuadernos de Pedagogía 264: 14-18.

CATALÁN, R. y L. EGAÑA, 2004. Valores, sociedad y educación. Una mirada desde los actores. LOM, Santiago.

CHIODI, F. y M. BAHAMONDES, 2001. Una escuela, diferentes culturas. Corporación Nacional de Desarrollo Indígena, Temuco.

DÍAZ DE RADA, A., 1996. Los primeros de la clase y los últimos románticos: Una etnografía para la crítica de la visión instrumental de la enseñanza. Siglo XXI, Madrid.

DIETZ, G., 2003 Hacia una antropología de la interculturalidad. Editorial Universidad de Granada, Granada. 
FERRAO, V., 2010. Educación intercultural en América Latina. Distintas concepciones y tensiones actuales. Estudios pedagógicos $36(2): 333-342$.

FRANZÉ, A., 2003. Lo que sabía no valía: Escuela, diversidad e inmigración. Consejo Económico y Social de la Comunidad de Madrid, Madrid.

GARCÍA CANCLINI, N., 2006. Diferentes, desiguales y desconectados. Mapas de la interculturalidad. Gedisa, Barcelona.

GEERTZ, C., 1997 [1973]. La interpretación de las culturas. Gedisa, Barcelona.

GÓMEZ, D., 1995. Cultura y educación atacameñas. Instituto de Investigaciones Antropológicas, Universidad de Antofagasta, Antofagasta.

GUNDERMANN, H., 2003. Sociedades indígenas, municipio y etnicidad: La transformación de los espacios políticos locales andinos en Chile. Estudios Atacameños 25: 55-77.

2004. Inicios de siglo en San Pedro de Atacama: Procesos, actores e imaginarios en una localidad andina. Chungara, Revista de Antropología Chilena 36 (1): 221-239.

HERNÁNDEZ, R., 2004. Evaluación de la eficiencia programática y la pertinencia intercultural del Programa de Educación Intercultural Bilingüe del Ministerio de Educación en escuelas de la región Metropolitana. Departamento de Antropología, Facultad de Ciencias Sociales, Universidad de Chile, Santiago.

HERNÁNDEZ, R. y C. THOMAS, 2004. Cultura, desarrollo y educación en las comunidades atacameñas de la II región de Chile. Revista Enfoques Educacionales 6: 93-114.

HEVIA, R. (Ed.), 2005. Políticas educativas de atención a la diversidad cultural: Brasil, Chile, Colombia, México y Perú. OREALC/ UNESCO, Santiago.

JOCILES, M., 2003. Escuela, etnia, cultura. Crítica de algunos maridajes teórico-metodológicos. En Entre la diferencia y el conflicto. Miradas etnográficas a la diversidad cultural en educación, D. Poveda (Ed.), pp. 185-210. Universidad de Castilla-La Mancha, Cuenca.

KYMLICKA, W., 1995. Multicultural citizenship: A liberal theory of minority rights. Clarendon, Oxford.

LAHIRE, B., 2007. Infancia y adolescencia: De los tiempos de socialización sometidos a constricciones múltiples. Revista de Antropología Social 16: 21-38.
LEYTON, D., 2010. Trayectorias del cuidado de la salud infantil en San Pedro de Atacama. Entre el manejo de la subalternidad y el imaginario del riesgo. Tesis para optar al diploma de Estudios Avanzados en Antropología. Departamento de Antropología Social y Pensamiento Filosófico Español, Universidad Autónoma de Madrid, Madrid.

MEAD, M., 1967 [1928]. Adolescencia, sexo y cultura en Samoa. Paidós, Buenos Aires.

MIDEPLAN, 2006. Memoria Programa Orígenes (2006). http:// www.origenes.cl/primera-fase.html

MINEDUC, 2005. Orientaciones Programa de Educación Intercultural Bilingüe. Santiago. www.mineduc.cl/biblio/documento/200510051917470.OPEIB2005.pdf

MONTENEGRO, M., 2010. El patrimonio arqueológico de Jujuy: Miradas diversas desde la escuela. Estudios sociales del N.O.A. Nueva Serie 1: 107-121.

2012. Arqueología en la escuela: Experiencias en el sector septentrional del Noroeste Argentino. Chungara, Revista de Antropología Chilena 44 (3): 487-498

NÚÑEZ, L., 2007. Vida y cultura en el oasis de San Pedro de Atacama. Editorial Universitaria, Santiago.

ROCKWELL, E.yA. GÓMEZ. 2009. Introduction to the special issue: Rethinking indigenous education from a Latin American perspective. Anthropology and Education Quarterly 40 (2): 97-109.

SANHUEZA, C. y H. GUNDERMANN, 2007. Estado, expansión capitalista y sujetos sociales en Atacama. Estudios Atacameños, Arqueología y Antropología Surandinas 34: 113-136.

SZULC, A., 2009. Becoming Neuquino in mapuzugun: Teaching Mapuche language and culture in the province of Neuquén, Argentina. Anthropology and Education Quarterly 40 (2): 129-149.

TAYLOR, C., 1994. Multiculturalism: Examining the politics of recognition. Princeton University Press, Princeton.

VELASCO, H., F. GARCÍA, y A. DÍAZ DE RADA (Eds.), 2006. Lecturas de antropología para educadores. Editorial Trotta, Madrid.

WILCOX, K., 2006 [1982]. La etnografía como una metodología y su aplicación al estudio de la escuela: Una revisión. En Lecturas de antropología para educadores, H. Velasco, F. García y A. Díaz de Rada (Eds.), pp. 95-126. Editorial Trotta, Madrid. 
WILLIAMSON, G., 2004. ¿Educación multicultural, educación intercultural bilingüe, educación indígena o educación intercultural? Cuadernos interculturales 3: 16-24.

2012. Institucionalización de la educación intercultural bilingüe en Chile. Notas y observaciones críticas. Perfiles educativos 34 (138): 126-147.
WILLIS, P., 2006 [1981]. Producción cultural no es lo mismo que reproducción cultural, que a su vez no es lo mismo que reproducción social, que tampoco es lo mismo que reproducción. En Lecturas de antropología para educadores, H. Velasco, F. García y A. Díaz de Rada (Eds.), pp. 431-461. Editorial Trotta, Madrid. 